\title{
Rethinking institutional excellence in Ethiopia: adapting and adopting the balanced scorecard (BSC) model
}

\author{
Tilaye Kassahun $^{1}$
}

\begin{abstract}
This paper intends to outline an academic scorecard that serves as a strategic framework for measuring institutional performance in Ethiopia. It gives major emphasis for producing initial portfolio of key performance indicators that will serve as a springboard for measuring performance in academic institutions. The study relied on meta-analysis of existing BSC-related literature in business and mission-driven organizations across the globe with an intention of benchmarking the best practices in the area. A comprehensive analysis and synthesis of an extant literature resulted in an architectural blueprint of BSC for academic institutions operating in Ethiopia. This has been built around five strategic themes that serve as pillars of excellence for HEIs (viz., academic excellence, diversity of student community, outreach and engagement, resource management, and networking and partnership) and four perspectives, which are different views of what drives the institution and those which provide a framework for measurement of its performance. The identified perspectives include the stakeholders, the internal business process, financial stewardships, and learning, innovation and development (LID). A number of strategic objectives and measurement metrics have been forwarded under each perspective in line with the HEI's mission. The researcher expects that such BSC framework will arouse a great deal of interest in opening discussions and debates among academics, HEIs officials, policy makers, reform consultants and others in a way they serve as a good ground for developing common understanding and outlining a skeleton of academic scorecard to be standardized for more or less uniform application in the Ethiopian HEIs.
\end{abstract}

Keywords: Balanced Score card (BSC), Ethiopian Higher Education Institutions, excellence in service provision.

\section{Introduction}

It has become an undeniable truth that the wealth of the nation depends more on its people, management and government, than on its natural resources. History has taught us adequately that the countries, which are now called as advanced and prosperous (like USA, Japan, Great Britain, Germany, Israel, the Netherlands) have achieved such a remarkable economic growth and development through their work alcoholic and innovative people. Education helps to enhance the knowledge base of the nation and therefore it plays a

\footnotetext{
${ }^{1}$ Dr Tilaye serves as an Asst. Professor of Management and as a Director for Research \& Consultancy Coordination Office at the Ethiopian Civil Service College. Address: P.O. Box-5658, Tel. 0911 837266, 0116463008; E-mail: tilayek@gmail.com.
} 
vital role in shaping the future of the nations. Emerging global trends, new economic challenges, the rapid growth of information technology (IT) and the requirement for multilingual proficiencies are some of the challenges that developing countries have to face. The role of education in building workforce and management capable enough to cope with these challenges has been appreciated and gained much more attention from various governments than ever before (Gill and Lashine, 2003). Particularly, higher education, as the ost important source of educated and skilled people, is increasingly recognized as an important way of forming rich human capital through providing high quality education and in addressing the pressing problems of a nation (Karname et al, 2004).

As a result, governments and societies are exerting mounting pressures on higher educational institutions to become active, creative and innovative, dynamic, responsive, demand-driven, quality conscious, result-oriented, efficient and effective so that they can play a significant role in transforming their societies. In this regard, a number of policy makers and academics are strongly criticizing the relevance and quality of educational programs offered by some traditional institutions. These circumstances do force educational institutions to manage themselves strategically and innovatively rather than traditionally (i.e. in business as usual mode). They need to define their future direction (vision, mission and goals) clearly and craft appropriate strategy to reach the desired destination successfully. As the saying goes, organizations without clear direction are considered as a ship without a rudder, whose fate is either getting crushed with a curved stone or going nowhere even if it pretends to.

Now-a-days strategic thought and strategy-based actions enable organizations to cope with and successfully adapt to the future environment (Kriemadis, 1997). Strategic plans depict the route from the present position to the future desirable position described by the vision (West-Burnham et al, 1994) and help the organization to improve its performance by better acquaintance of the environment (Kraus et al, 2006). These are the main reasons why the evaluation of competitive environment of the organization and its strategic position is necessary in strategic planning process (Tsiakkiros and Pashiardis, 2002).

In particular, in today's knowledge-based economy, higher education institutions (HEIs) as the centers of developing human resource play vital role in countries' economic growth and development processes (King, 1995). So strategic planning has got a vital importance for such institutions 
(Kriemadis, 1997) and leads them to better future by adapting to the environment beside the educational policies (Kettunen, 2006). However, this writer restrains himself from hastily generalizing that strategic planning serves as a panacea for all types of management failures. Because, in many cases, a good strategic plan may not be fully implemented for a number of barriers, such as vision barrier, people barrier, resource barrier, and management barrier (Balanced Scorecard Collaborative, 2002). These are briefly explained as under:

Vision barrier - No one in the organization understands the strategies of the organization.

People barrier - Most people have objectives that are not linked to the strategy of the organization.

Resource barrier - Time, energy, and money are not allocated to those things that are critical to the organization. For example, budgets are not linked to strategy, resulting in wasted resources.

Management barrier - Management spends too little time on strategy and too much time on short-term tactical decisionmaking.

To substantiate the above description, research findings indicate that, most often than not, only 5 percent of the workforce understands their company strategy, 25 percent of managers have incentives linked to strategy, 60 percent of organizations don't link budgets to strategy, and 86 percent of executive teams spend less than one hour per month discussing strategy (Balanced Scorecard Collaborative, 2002: 2)

To ameliorate such unnecessary failure of implementing a strategic plan, experts recommend putting in place a new way of communicating strategy to the end-user, i.e. applying the Balanced Scorecard (BSC) approach. With BSC, strategy reaches everyone in a language that makes sense. When strategy is expressed in terms of measurements and targets, the employee can relate to what must happen. This leads to much better execution of strategy.

Not only does BSC transform how the strategic plan is expressed, but it also pulls everything together. This is the so-called "cause and effect" relationship or linking of all elements together. For example, if you want strong financial results, you must have great customer service. If you want great customer service, you must have excellent business processes in place (such as Customer Relations Management). If you want great business 
processes, you must have the right people, knowledge, and systems (intellectual capital).

Thus, as part of their strategic management processes, HEIs must identify strategic objectives and measure their performances (process outcomes) from different perspectives. This paper tries to explore the possibilities of applying the Balanced Scorecard (BSC) model in measuring the performances of HEIs in Ethiopia.

\section{Objectives of the Study}

This is an exploratory study whose main intention is to analyze and synthesize the existing body of knowledge in the area of balanced scorecard and examine the possibilities of adopting and adapting it in the Ethiopian higher learning institutions. More specifically, the study intends to address the following specific objectives:

1. To review various works and examine the relevance of BSC in educational settings

2. To explore the possibilities and key considerations in adapting and adopting the BSC in HEIs of Ethiopia

3. To craft academic scorecard that serves as a strategic framework for measuring institutional performance so as to create academic and service excellences, and

4. To suggest appropriate mechanisms of implementing academic scorecard in Ethiopia.

\section{Rationale of the Study}

A couple of reasons that encouraged this researcher to undertake this study are as follows:

i. It is a widely shared understanding that Ethiopia has survived with very limited higher learning opportunities for many decades. However, more recently, the doors are being widely open for potential learners to get access to educational opportunities at various levels-more universities and colleges are being opened in the last few years. This quantitative surge requires quality checks/controls through systematic management tool. There is a consensus among scholars that establishing BSC serves as an important tool to measure and maintain academic excellence in higher learning institutions. 
ii. In its desire to bring about national transformation in the shortest possible time, the Ethiopian Government is working hard to realize its vision of making the country as one of the middleincome countries by 2025 . To this end, it has put in place an aggressive and a comprehensive civil service reform across the country. As a result, almost all public organizations, including HEIs are under reform since 2002. Business Process Reengineering (BPR) is chosen as the main reform tool to be applied across the country. Establishing an integrated performance management system is one of the requirements of BPR for which BSC is found to be the right fit for the kind of change that is being practiced in the country. Unlike the traditional higher education performance measurement system that relies on such indicators as enrollment ratio, number of graduates ... etc, the BSC is an integrated management approach that employs both the lagging and the leading indicators of educational performance measurement. This makes it the need of the hour.

iii. No higher education in Ethiopia has ever established BSC. However, when it comes to global setting, BSC is believed to be widely used in business enterprises (e.g. about 65\% of Fortune 1000 companies are using it) and a good number of HEIs have introduced it in various countries (Kaplan and Norton, 2001). Therefore, this researcher (as he himself is part of the taskforce created to develop a five-year strategic plan and establish BSC for the Ethiopian Civil service College, which is serving as an agent of change at national level) feels that examining the practice of BSC in various international organizations and HEIs will contribute something of value in customizing and creating a theoretical framework suitable to the Ethiopian HEIs system. In this sense, the present work can be considered as an eye-opener for those who are great interest in creating and developing a BSC culture in the Ethiopian education system in general and that of higher learning institutions in particular.

\section{Methodology}

The fact that no higher learning institution has ever introduced BSC culture in Ethiopia has constrained this researcher's ambition of conducting a fullfledged study based on primary sources of information. As a result, this 
study was limited to meta-analysis research technique, which relied largely on analysis and synthesis of the secondary data from available literature. Though this approach, relevant sources of secondary data including the seminal works of Robert S. Kaplan and David P. Norton (1992, 1993, 1996, 2000, \& 2001) and others' (e.g. Al-Anzi \& Alatiqi, 2006; Balanced Scorecard Institute's works, 1998-2009; Baldrige National Quality Program, 2003; Barnes, 2007; Brancato, 1995; Cullen, Joyce, Hassall \& Broadbent, 2003; Gill \& Lashine, 2003; Karathanos \& Karathanose, 2005; Kettunen, 2006; Kriemadis, 1997; Niven, 2003; O’Neil \& Bensimon, 1999; Ruben, 1999; Stewart \& Carpenter-Hubin, 2001; Umashankar \& Dutta, 2007; Pineno, 2007; West-Burnham \& West-Burnham, 1994; Yek, Penney, \& Seow, 2007) have been critically reviewed. In terms of cross-national mix, relevant works have been examined from Africa, Asia, Europe, Middle-East, and USA.

\section{Limitations}

As stated in one of the sections above, since this is an initial idea brought forth for discussion by academics and practitioners in Ethiopia, the study does not claim itself exhaustive as it does not involve primary data. Moreover, the study has not exhaustively treated all the necessary steps of creating BSC in an organizational setting as it did not focus on one particular institution in Ethiopia. But it provides a general framework by highlighting key considerations of the BSC for any higher learning institution operating in Ethiopia.

Thus, this study can be considered as a BSC menu for higher learning institutions in Ethiopia so that they can choose and pick any combination of considerations in order to build their own BSC framework as per their mission and strategic direction. It can also be considered as an eye-opener for others to use it as a steppingstone for further study in the integrated performance management system with special emphasis on the Ethiopian higher learning institutions. In this regard, the researcher suggests that this prilinary work has to be developed further through subsequent discussions with researchers, experts and practitioners in Ethiopian higher learning institutions, Ministry of Capacity Building, and Ministry of Education.

\section{Why do we need to implement a balanced scorecard?}

If we can't measure our processes, we can't manage our processes. If we can't manage our processes, we can't improve our processes. If we can't improve our processes, we can't meet or exceed our customers' expectations. What gets measured gets done. Measurement is core of the Balanced Scorecard-BSC (Kaplan and Norton, 1996). 
To ensure their survival and growth in this neck-to-neck racing business environment, organizations need to measure their performance from time to time and make the necessary adjustments depending on circumstantial factors. Measuring organizational performance strongly affects the behavior of people from within and outside of an organization. The measurement system employed by the organization needs to be holistic one that is derived from its strategy and capabilities (Kaplan \& Norton, 1992).

As Ruben (1999) has put it "one of the defining themes of contemporary organizational theory is the emphasis of information and measurement for assessing, tracking and promoting organizational excellence.” Almost all company managers have no dought to believe in the necessity of measuring organizational performance. The problem, however, arises when it comes to what should be measured and how it should be measured. Traditionally, forprofit organizations have measured their performances using a financial accounting model that emphasizes profitability, return on investment, sales growth, cash flow or economic value added (Ruben, 1999). However, study after study indicated that finance-based measures have inherent drawbacks to sufficiently represent the range of factors associated with organizational excellence in modern times (Brancato, 1995; Kaplan and Norton, 1992, 1996, 2001; Ruben, 1992). In particular, Kaplan and Norton (1992) have pointed out that accounting-based measures: (1) are too historical; (2) lack predictive power; (3) reward the wrong behavior; (4) are focused on inputs and not outputs; (5) do not capture key business changes until it is too late; (6) reflect functions, not cross-functional processes within a company; and (7) give inadequate consideration to difficult-to-quantify resources such as intellectual capital. Ruben (1999) has also suggested that accounting-based measures are unable to capture key elements of an organization's mission, customer satisfaction and loyalty, employee satisfaction and turnover, employee capability, organizational adaptability or innovation, environmental competitiveness, research and development productivity, market growth and success, and other important company-specific factors.

Recognizing some of the weaknesses and vagueness of previous management approaches, Kaplan and Norton (ibid) have introduced the balanced scorecard approach in 1992. From its outset, the Kaplan and Norton's balanced scorecard looks at a company from four perspectives:

1. The financial perspective. Measures in this perspective should answer the question, "How should we appear to our shareholders?"

2. The customer perspective. These measures should answer the question, "How should we appear to our customers?" 
3. Internal business processes perspective. Measures in this perspective should answer the question, "What processes must we excel at?"

4. Learning and growth perspective. These measures should answer the question, "How can we sustain our ability to change and improve?"

The diagram integrating the four perspectives has been displayed in Figure 1.

Figure 1. The Balanced Scorecard Framework

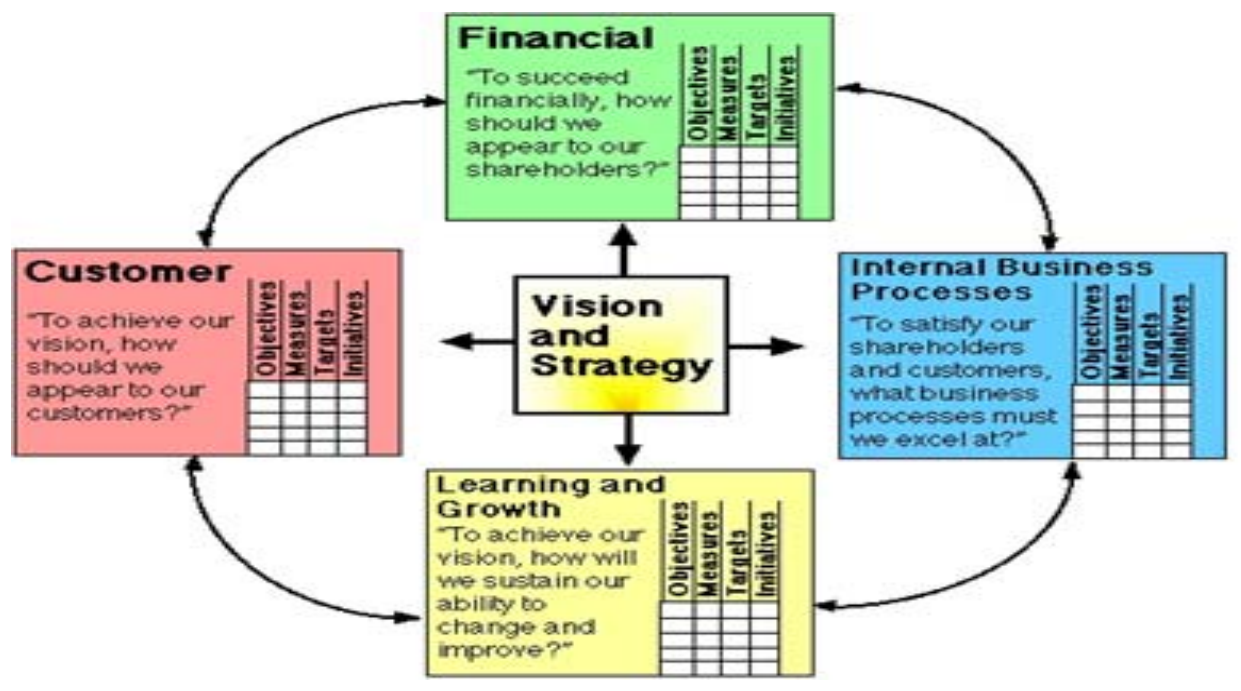

Source: Kaplan \& Norton, 1996: 7.

By viewing the organization from all four perspectives, the balanced scorecard provides a more comprehensive understanding of its current performance. In particular, BSC provides a clear prescription as to what companies should measure in order to 'balance' the financial perspective.

Kaplan and Norton (cited in the Balanced Scorecard Institute, 2009) describe the innovation of the balanced scorecard as follows:

The balanced scorecard retains traditional financial measures. But financial measures tell the story of past events, an adequate story for industrial age companies for which investments in long-term capabilities and customer relationships were not critical for success. These financial measures are inadequate, however, for guiding and evaluating the journey that information age companies must make to create future value through investment in customers, suppliers, employees, processes, technology, and innovation. 
In essence, the BSC is a customer-based planning and process improvement system aimed at focusing and driving the change process. It does this by translating strategy into an integrated set of financial and non-financial measures that both communicates the organizational strategy to the members and provides them with actionable feedback on attainment of objectives.

Kaplan and Norton (1996) argue that the BSC is a management system (not only a measurement system) that enables organizations to clarify their vision and strategy and translate them into action. It provides feedback around both the internal business processes and external outcomes in order to continuously improve strategic performance and results. When fully deployed, the BSC transforms strategic planning from an academic exercise into the nerve center of an enterprise. More specifically, the BSC has brought a revolution into performance measurement as it provides the following benefits:

i) It helps to clarify and gain consensus about strategy;

ii) It improves communication of the organization's Vision and Strategy;

iii) It links strategic objectives to long-term targets and annual budgets;

iv) It increases focus on organizational strategy and results;

v) It improves organizational performance by measuring what matters;

vi) It aligns organization strategy with the work people do on a day-today basis, align departmental and personal goals to the strategy;

vii) It focuses on the drivers of future performance;

viii) It encourages organization perform periodic and systematic strategic reviews;

ix) It helps to prioritize projects/initiatives; and

$\mathrm{x}$ ) It helps organizations to obtain feedback to learn about and improve strategy (Kaplan and Norton, 2001; 1996).

In summary, it is possible to say that BSC enables managers to craft organizational strategies in line with their vision, define strategic objectives in line with organizational mission and vision, develop strategic plan by integrating various issues, monitor and adjust the implementation of their strategies and to make fundamental changes in them. If used correctly, BSC not only creates concrete results, but also creates a long-term balance in the organization. This balance can be described from many different angles. It provides a balance between the short-term and the long-term. This means that it offers a balance between what is important today and what is important tomorrow. It also gives a balance between external and internal measures, indicating a balance between what is important to us and to our 
key stakeholders. Moreover, BSC gives you a balance between financial (hard) and non-financial (soft) measures. Finally, it gives a balance between different levels in the company. This balance is the one established between what is important to the management and what is important to all employees.

Kaplan and Norton (ibid) have shown in their latest research that the BSC also can produce the promised effects. Examples of these results can be seen in companies such as Mobil Oil and Rockwater, which have increased their competitiveness and profitability considerably with the implementation of the BSC. Having realized such benefits of BSC, a large number of companies have been adopting it since 1990s. In their study, Kaplan and Norton (2001) reported that by 2001 about 50 percent of the Fortune 1000 companies in North America and about 45 percent of companies in Europe were using the BSC.

\section{Application of BSC in Education}

According Kaplan and Norton (1992, 1996, 2001), all organizations (forprofit and not-for-profit) can adapt BSC. In reality, however, the business sector organizations seem to have adopted it more widely than not-for-profit organizations. In particular, the education sector apparently has not embraced the BSC concept widely, as indicated by the dearth of published research on this topic. But, through time, BSC is making inroads to educational institutions in various parts of the world.

In this regard, a thorough review of the literature has traced some publications that highlighted significant achievements of various educational institutions. For example, Barnes (2007) reported that BSCard has been established in the University of Kuzulu-Natal (UKZN) to achieve three objectives: (1) to establish an ongoing system of institutional evaluation for the purpose of annual reporting, (2) to support the annual faculty evaluation process which informs the allocation of resources to faculties and colleges, and (3) to assist the institutional audit process of the Higher Education Quality Committee (HEQC) in 2008. Similarly, other researchers (Cullen, Joyce, Hassall \& Broadbent, 2003) proposed that a Balanced Scorecard be used in educational institutions for reinforcement of the importance of managing rather than just monitoring performance. O’Neil and Bensimon (1999) described how a faculty committee at the Rossier School of Education of University of Southern California adapted a Balanced Scorecard model originally developed for business firms to satisfy the central administration's need to know how they measure up to other schools of education. The format of the Balanced Scorecard adapted by the faculty 
included the following four perspectives: 1) academic management perspective (How do we look to our university leadership?); 2) the internal business perspective (What we excel at?); 3) the innovation and learning perspective (Can we continue to improve and create value?); 4) the stakeholder perspective (how do students and employers see us?). O'Neil and Bensimon (1999) indicated the following favorable results from the "academic" scorecard implementation:

- Easier approach for the university to accomplish its strategic goals.

- A systematic and consistent way for the provost's office to evaluate performance reports from various schools and departments.

- The scorecard established common measures across academic units that have shared characteristics.

- The simplicity of the scorecard makes it easier for academic units to show how budget allocations are linked to the metrics of excellence.

Stressing the importance of adopting and adapting BSC to ensure academic excellence in USA, Baldrige National Quality Program (2003: 4) states that "the use of a balanced composite of leading and lagging performance measures offers an effective means to communicate short- and longer-term priorities, monitor actual performance, and provide a clear basis for improving results.” Also, Chang and Chow (1999) indicated that in 1993 the University of California, San Diego's senior management launched a Balanced Scorecard planning and performance monitoring system for 30 institutional functions using three primary data sources: 1) UCSD's internal financial reports; 2) National Association of College and University Business Officers benchmarks; and 3) faculty, staff and student customer-satisfaction surveys. This exercise was conducted under the framework of the university's vision, mission, and values. Reported benefits and outcomes to date have included reorganization of the workload in the vice chancellor's area, revision of job descriptions with performance standards, introduction of continual training for user departments, ongoing customer assessments and increased responsiveness to communication needs through the use of technology. The researchers have also reported that responses in a survey of 69 accounting department heads were generally supportive of the BSC's applicability and benefits to accounting programs.

Chen et al. (2006), in their study, have focused on the use of BSC to establish an evaluation system for the performance of Chin-Min Institute of Technology (CMIT). Umashankar and Dutta (2007) proposed a BSC model 
which can be applied to Indian higher education programs/institutions. Papenhausen and Einstein (2006) lay out a comprehensive and contentspecific BSC for a business school as a whole. The researchers proposed that in an environment that demands increasing accountability from business schools, the BSC approach offers a promising and valuable tool for implementing a strategic performance management system in a college of business.

Yek, Penney and Seow (2007), on their part, have also reported a successful BSC practice from Singapore's Institute of Technical Education (ITE). As the first education institution to win the prestigious Singapore Quality Award in October 2005 and one of only 22 organizations to win the award since it was launched in 1994 (ITE, 2006), ITE can be considered as a world-class VET institution. Its world-class status was further affirmed on September 25, 2007, when the Ash Institute for Democratic Governance and Innovation at Harvard University's John F. Kennedy School of Government announced ITE as "the winner of the (US) $\$ 100,000$ IBM Innovations Award in Transforming Government” (IBM, 2007). This achievement can be attributed to ITE's tradition of performance measurement since its inception in 1992, which has, in turn, led to the formal adoption of BSC as a strategic management system since 2002 in an endeavor to enhance quality and performance within the institution.

To sum up, although the BSC approach to measure organizational performance has been widely adopted in business organizations, higher educational institutions are gradually adopting it in order to ensure their survival and growth. Nowadays the environment demands increasing accountability from higher educational institutions if they fail to meet stakeholder expectations by designing relevant and quality programs from time to time. In this regard, a successful BSC can provide feedback to the administration and faculty that can lead to a long-term process that will foster individual and collective growth resulting in improved overall organizational performance.

\section{Adopting and Adapting BSC in the Ethiopian Higher Education Institutions}

As discussed in the previous sections of this paper, all types of organizations irrespective of their mission are currently re-conceptualizing measurement indices to come up with relevant excellence indicators. Accordingly, higher education institutions world-over are facing the challenges of being centers of excellence for teaching, research, training and consultancy services. Such pressures also do prevail in the Ethiopian HEIs. The fact that the Ethiopian 
Government has launched a massive civil service reform program throughout the country as of 2002, all public institutions are compelled to re-engineer their services to become responsive, efficient and effective. To show its firm conviction and dedication towards institutional excellence, the Ethiopian Government has issued a new proclamation for higher education institutions in 2009. The proclamation pays special emphasis to the roles of HEIs in transforming the Ethiopian society by serving as centers of academic excellence, institutional transformation and technological transfer; shapers of youth behavior and human talent; prompters of peace, stability and democratic ideals in the country; and facilitators of the country's competitiveness in a global setting.

As a result, public HEIs across the country are facing the challenges of restructuring and reforming themselves so that they provide quality education and bring up graduates who become fruitful members of their societies. They are also expected to engage themselves in research and consultancy services so that they tackle the pressing multi-faceted problems of the country and transform Ethiopia.

As in business, in higher education there are acceptable conventions of measuring excellence. As opposed to accounting-based measures dominantly used in businesses, HEIs have historically emphasized academic measures. In particular, measurement in HEIs has generally focused on quantifiable academic indicators, such as student and faculty demographics, facultystudent ratios, enrollment (by sex, ethnicity and program level), graduation rates, dropout rates, repetition rates, grade point average, class rank, faculty teaching loads and instructional contact hours, academic and administrative staff ratios, statistics in physical and library sources, budget utilization level, and other similar factors (MOE, 2007; Ruben, 1999; Ewell, 1994).

However, these traditional measures of institutional performance fail to provide a comprehensive list of indicators that help to assess the academic excellence of the institution. In view of this, Ruben (1999) points out that the traditional indicators of HEIs performance do not embrace some of the key success factors for an institution, nor do they capture the institution's mission, vision, or strategic directions. In addition, the traditional indicators have failed to integrate lagging indicators and leading indicators in a way they add value to the performance measurement of HEIs. For example, measures such as student grade-point average (GPA) or standardized test score capture "input" - the capabilities students bring with them to a given institution—but often not the value the institution adds through its effective teaching-and-learning process, nor "outputs", or benefits derived from 
having attended (Ruben, 1999). Rubben (1999) further describes the limitations of the traditional educational measurement tools as follows:

i. Indicators such as GPA and test scores inform us about the students, but they do not tell us what staff people are doing to make this an excellent institution.

ii. Indicators such as GPAs and test scores are to some degree "historical"; they are a measure of what already happened. If we are making mistakes, we might find out long after the fact.

iii. The traditional indicators are not necessarily good at telling us to how well we are accomplishing the goals as stated in the institutions' missions or strategic plans.

iv. The traditional indicators do not reflect the work that many perhaps a majority - of the people who work here are doing.

v. The traditional indicators do not describe to what degree we are performing other tasks we do that contribute to the long-term prospects of the institution, such as attracting and retaining highquality faculty, staff and students.

Similarly, other researchers (Astin, 1993; Johnson \& Seyomour, 1996) have reported that traditional measurement framework that has been adopted in HEIs fails to embrace important indicators that are useful for monitoring, intervening in, or comparing institutional excellence. Other factors which are less obviously linked to academics, less tangible, or less readily susceptible to quantitative analysis have been disregarded from the measurement menu. Thus, important measurement dimensions, such as program relevance, need, accessibility, fulfillment of expectations, value-added during the teachinglearning process, issues of equity and equality, staff and student satisfaction levels, impact and motivation for life-long learning, and employers and community satisfaction levels are not commonly used indicators of academic excellence.

Cognizant of such a reality, nowadays, accountability in higher education has become a challenging issue for higher education in Ethiopia. Increasingly, institutions of higher learning have been required to provide performance indicators - empirical evidence of their value - to government, general public, students, alumni, prospective students, staff, employers and other external stakeholders. As a result, the implementation of Balanced Scorecard in higher education, as a corollary to BPR, has been a target of interest in recent years. However, there is still a big challenge in creating a comprehensive BSC framework that truly reflects all the indicators for measuring the performances of HEIs. This happens to be particularly the case in HEIs presently operating in Ethiopia. 
At present, all public institutions have been undertaking business process reengineering (BPR) which does require the establishment of BSC as a strategic planning and management tool. As no higher education institution in Ethiopia has ever experienced with BSC approach to measure its performance, building BSC has become an echelon-of-the-hill to all HEIs across the country. Recognizing the situation on the ground, this researcher tending a suggestion to bring BSC in the limelight of Ethiopian HEIs.

In adopting BSC model in the Ethiopian HEIs context, the researcher has made an exhaustive review of various BSC-related documents across the globe (e.g. Al-Anzi and Alatiqi, 2006; Balanced Scorecard Institute, 19982009; Baldrige Criteria for Performance Excellence, 2004; Barns, 2007; Cullen et al., 2003; Kaplan and Norton, 1992, 1996, 2001; Karathanos and Karathanos, 2005; Ruben 1999; Umashankar and Dutta, 2007; Yek et al, 2007).

Having reviewed an extant literature, the researcher reached the conclusion that higher education institutions' management and measurement system has to facilitate the accomplishment of the fundamental mission: advancement of excellence in creation, innovation, dissemination, and application of knowledge through teaching, research/scholarship, and consultancy services provided to its key stakeholders. The fulfillment of such a mission requires thorough identification and successful engagement of the institution with key stakeholders. In addition, the institutions have to understand/analyze needs and expectations of their internal and external key stakeholders from time to time so as to come up with relevant and valid indicators of its performance. The key stakeholders of a higher education institution could be potential students, current students, families, alumni, contracting agencies for research and consultancy services, employers, other sisterly institutions, colleagues in other institutions, government agencies (standardizing and legislative authorities), the general public, governing boards, academic and administrative staff, and others (friends, interested individuals, donors, etc.). By looking into the possible broad-based needs and expectations of these stakeholders, the architecture of the balanced scorecard framework was created as under.

\section{The BSC Framework}

One of the main tasks of building BSC is to identify key performance areas (or strategic themes) and key performance indicators (PIs) or perspectives of the institution. 
Strategic themes: these are fundamental policy or program concerns that define the most important issues that do have a significant bearing on an institution's business. They reflect major shifts in thinking that challenge the business as usual and the major focus areas that the institution wants to build excellence. That is why they are often called as the 'pillars of excellence' for the institution. Strategic themes define the scope for building the balanced scorecard system. The possible strategic themes for a higher education institution can include:

1. Academic excellence: What is the institution's contribution to the creation and transfer of knowledge? This is particularly seen in terms of evaluating the institution's effort and capacity to create new knowledge through education and research or scholarship and properly transferring it to its students.

2. Diversity: How well does the institution broaden and strengthen its community?

3. Outreach and engagement: How effectively does the institution transfer knowledge to local, national, and international communities?

4. Resource management: How well does the institution develop and manage resources/overall capacity?

5. Networking and partnership: To what extent does the institution create and maintain linkages and networks with various local and international organizations or institutions?

Perspectives: they are different views of what drives an institution and those which provide a framework for measurement. The identification of perspectives needs to be done in an informed manner considering the strategic themes and strategic objectives of the institution and it has to be in line with what has been stated in its strategic plan (Barnes, 2007). The creators of the BSC (Kaplan and Norton, 1992) had outlined the four perspectives of business performance measures (viz., finance, customer, internal business process, and learning and growth perspectives). They stressed that each perspective in the BSC is a lens through which to view performance of an organization.

When it comes to an educational setting, different educational institutions have tried to define different perspectives depending on their strategy. For example, Baldrige National Quality Program (2003) in USA has suggested six major constituents of a balanced performance measurement method. These include: 
(1) Student learning results; (2) student- and stakeholder-focused results; (3) budgetary, financial, and market results; (4) faculty and staff results; (5) organizational effectiveness results, including key internal operational performance measures; and (6) governance and social responsibility results.

In a slightly different viewpoint, Ruben (1999) has proposed five indicator clusters to capture all dimensions of an HEI's mission, vision or strategic directions: teaching/learning, public service/outreach, scholarship/research, workplace satisfaction, and financial clusters. In support of this approach, University of Kuzulu-Natal (UKZN) has adopted the five clusters as finance, outreach (community development and engagement), research, staff, and student, which are further broken down into 64 specific performance indicators (Barnes, 2007).

On the other hand, Al-Anzi and Alatiqi (2006) introduced an integrated framework for self-assessment at the College of Engineering and Petroleum in Kuwait University, and suggested five categories of assessment, including: (i) productivity, (ii) efficiency, (iii) effectiveness, (iv) internal structure, and (v) growth and development. Yek et al, (2007) have adopted the three perspectives of Kaplan and Norton but replaced financial perspective with stakeholder perspective at ITE in Singapore. Umashankar and Dutta (2007) have suggested the adoption of the four perspectives as forwarded by Kaplan and Norton (1992) but with proper customization of the specific performance indicators to suit to higher educational settings in India.

After having analyzed all viewpoints and practical reports, the present researcher has proposed the four perspectives to be adjusted in a way they are integrated with mission, vision, and strategic directions of a higher education institution operating in Ethiopia. The proposed four clusters of HEI's performance measurement system include: (1) Stakeholder perspective, (2) Internal business process perspective, (3) Financial stewardship perspective, and (4) Learning, innovation and development perspective (as shown in fig. 3). 
Figure 3. The BSC Framework for HEIs in Ethiopia

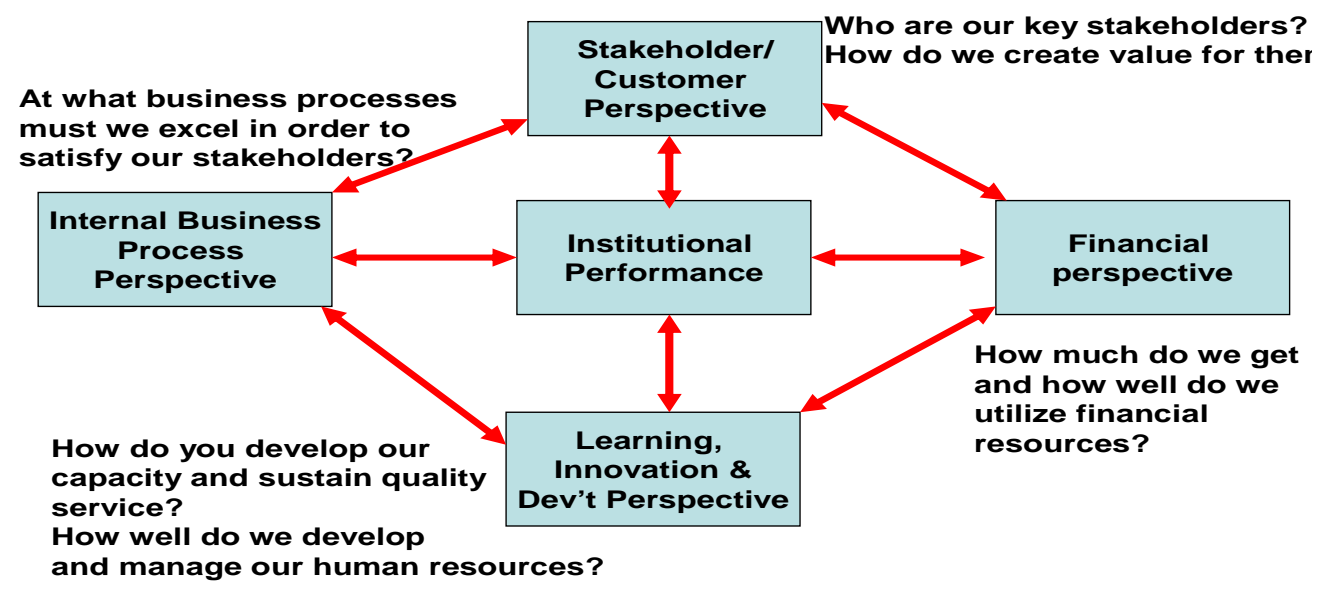

These performance perspectives have been built around five major strategic thrusts (themes) of a higher education institution as discussed above. The integration of the four perspectives with the five strategic themes can be displayed as under.

Figure 4 Integration of Strategic Themes with Perspectives

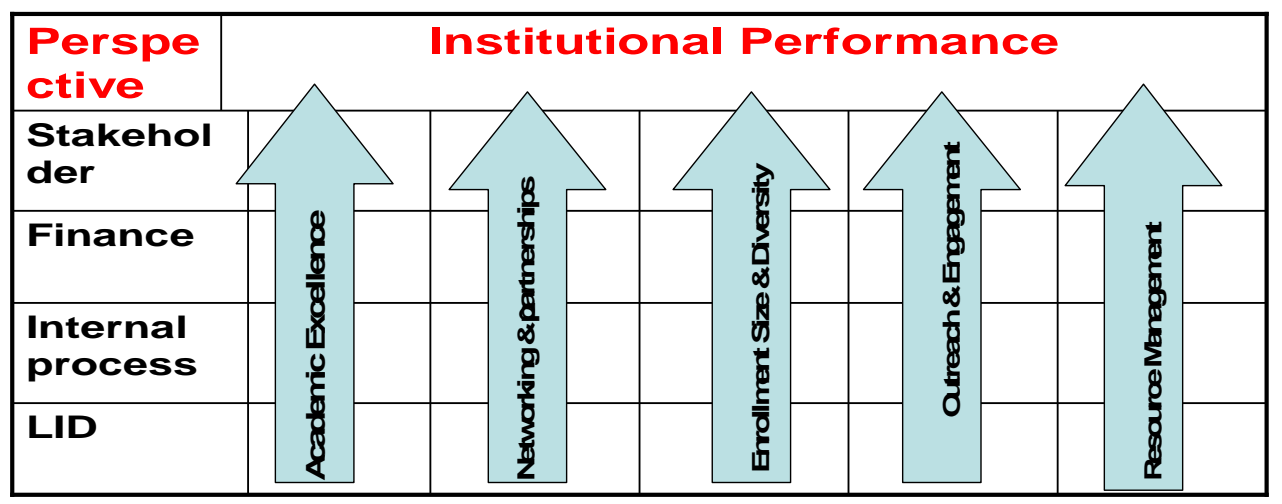

In light of this framework, the academic scorecard can be developed by identifying strategic objectives associated with each of the perspectives, which are built on the five strategic themes. Each objective will, in turn, has specific performance measures that indicates progress toward attaining improvement in the designated performance area. 
The four perspectives have been adapted to reflect performance indicators relevant to higher education. For example, with the original BSC model developed from a business organization viewpoint, it is important to balance measures from the Financial Perspective with measures from the Customer Perspective, Internal Business Perspective as well as Innovation and Learning Perspective. However, most HEIs in Ethiopia are public funded not-for-profit academic institutions. So from this viewpoint, while costs are important, HEIs would not be driven by the financial bottom line. Instead, the educational institutions are driven by meeting the needs and expectations of their key stakeholders/customers, such as meeting the needs of students to get access to relevant and quality programs, satisfy employers by producing competent graduates, create further educational opportunities for alumni and potential learners, and provide support for local community at large.

At this juncture, academics and practitioners must get the crystal ball clear from the outset that a clear distinction between business enterprises and notfor-profit HEI's Balanced Scorecards is drawn as a result of placing stakeholders at the top of the framework. A successful achievement of HEI's mission lies in not generating profit to the owners but it must be able to satisfy the interests of diverse groups. In other words, in the profit seeking world, companies are accountable to their capital providers (shareholders) for results, and they monitor this accountability through the results attained in the financial perspective of the scorecard. However, this is not the case in the non-profit and mission-driven organizations like public HEIs as their prime focus is on customers, and serving their needs in order to accomplish the mission. In this respect, this researcher strongly believes that HEIs in Ethiopia have significantly changed their customer-orientation mindsets as a result of the recent BPR implementation effort, which emphasizes giving due respect for all customers (including students) and becoming responsive to their demands. There is a growing acceptance that HEI's administration must understand and address the wants, needs and requirements of those it serves. Taking the customer view means focusing on responsiveness, timeliness, product and service quality and cost—from the customer point of view.

When developing objectives and measures for Internal Business Process Perspective we ask ourselves, "What are the key internal processes we must excel at in order to drive value for our customers?" In this regard, the Ethiopian HEIs-BSC model looks at key business processes as well as support processes in a highly-integrated approach to ensure that their products and services meet customer and operational requirements. Internal business process measures focus inward into the internal workings of the business area, on those processes and activities that deliver critical services 
to both internal and external customers. These are the measures that tell the story of effectively and efficiently integrating various core businesses (i.e. education, training, research and consultancy services), core business processes with support business processes, efficient maintenance and troubleshooting services, effective recruiting and hiring, quick turn-around on employee inquiries into retirement benefits and efficient hazardous waste disposal programs. Internal business process measures address such things as productivity, accuracy, cycle time, core competencies and effective use of people and information resources, and other similar factors.

In the case of financial stewardship perspective, HEIs have to measure their ability to budget their resources and utilize the budget according to their plan of action (instructional and research endeavors), ability to generate incomes, ability to maximize resource utilization, amount dedicated to increase research and scholarship grants. In this sense, financial indicators are considered as important enablers of customer satisfaction. It must be understood that in the absence of adequate financial resources, the organization cannot achieve its mission nor can it meet the expectations of its key stakeholders.

Regarding learning, innovation and development perspective, HEIs in Ethiopia should believe in that developing the competencies of their staffs and developing their institutional capacity serve as foundations for fulfilling their mission. Operating as mission-driven organizations, HEIs rely heavily on the skills, dedication, and alignment of their staff to achieve their socially important goals (Kaplan, 2002). Employees and organizational infrastructure represent the thread that weaves through the rest of the Balanced Scorecard. Success in driving process improvements, operating in a fiscally responsible way, and meeting the needs of all customer groups depends to a large extent on the ability of employees and the tools they use in support of your mission. Motivated employees with the right mix of skills and tools operating in an organizational climate designed for sustaining improvements are the key ingredients in driving process improvements, working within financial limitations, and ultimately driving customer satisfaction and mission success. Thus, this category of the BSC must reflect the institution's ability to sustain high performance levels over time. Here, we examine the more subjective factors that contribute to high performance, such as workplace climate, employee morale, team spirit or group cohesiveness, attitudes towards change, degree of participation in decision-making, skill alignment, opportunities for creativity and innovation, professional development strategies and effective use of technology. 
The central pitch of the BSC framework is the Institutional Performance, which is attained through the realization of the institution's vision, strategic themes, and strategic objectives. Each of the perspectives must be linked and contribute their share to the attainment of the overall institutional performance.

\section{Building HEIs scorecard matrix: perspectives, objectives, outcome measures/indicators}

In light of the above mentioned four perspectives, an attempt has been made to construct the HEI-BSC matrix composed of perspectives, possible strategic objectives, and measures or indicators. To make the matrix complete, institutions must identify possible projects/initiatives and targets to be achieved as per their vision, strategic directions, and internal make-ups. Table 1 provides an example of the scorecard and associated with each perspective. In this regard, readers are advised to consider this as an indicative list of strategic objectives and performance indicators that can be adjusted as per the vision and strategic direction of a particular higher education institution.

Table 1 Sample HEIs Scorecard Matrix

\begin{tabular}{|c|c|c|}
\hline $\begin{array}{c}\text { Perspectives \& } \\
\text { strategic questions }\end{array}$ & Strategic Objectives & Outcome Measures/Indicators \\
\hline \multirow{5}{*}{$\begin{array}{l}\text { 1. Stakeholders' } \\
\text { perspective } \\
\text { (Students, } \\
\text { parents, } \\
\text { alumni, } \\
\text { legislators, } \\
\text { accrediting } \\
\text { agencies, } \\
\text { donors, } \\
\text { community, } \\
\text { governing } \\
\text { boards, faculty } \\
\text { \& staff). How } \\
\text { do we create } \\
\text { value for } \\
\text { them? }\end{array}$} & $\begin{array}{l}\text { Increase student access } \\
\text { and in-take diversity }\end{array}$ & $\begin{array}{l}\text { Size of students in various programs, } \\
\text { market share of student enrollment, } \\
\text { and level of campus diversity in terms } \\
\text { of sex, health, geography \& ethnicity. }\end{array}$ \\
\hline & $\begin{array}{lr}\text { Attract } & \text { high-quality } \\
\text { students into various } \\
\text { programs }\end{array}$ & $\begin{array}{l}\text { Matriculation results, entrance exam } \\
\text { results, undergraduate grades, project } \\
\text { performances, work experience }\end{array}$ \\
\hline & $\begin{array}{l}\text { Improve student progress } \\
\text { (success rate) in targeted } \\
\text { programs }\end{array}$ & Retention \& graduation rates \\
\hline & $\begin{array}{lr}\text { Increase } & \text { student } \\
\text { satisfaction } & \text { (with } \\
\text { relevance \& quality of } & \text { \&rograms, flexibility of } \\
\text { programs, academic } \& \\
\text { admin services) }\end{array}$ & $\begin{array}{l}\text { Student survey results, variety of } \\
\text { programs and delivery schemes, } \\
\text { catering services, communication } \\
\text { system }\end{array}$ \\
\hline & $\begin{array}{l}\text { Increase employers' } \\
\text { satisfaction with graduates }\end{array}$ & $\begin{array}{l}\text { No. of organizations recruiting on } \\
\text { campus, employer survey rating } \\
\text { graduates, effectiveness, perception } \\
\text { surveys, support of programs \& } \\
\text { initiatives, average starting salary of } \\
\text { graduates, placement trends }\end{array}$ \\
\hline
\end{tabular}




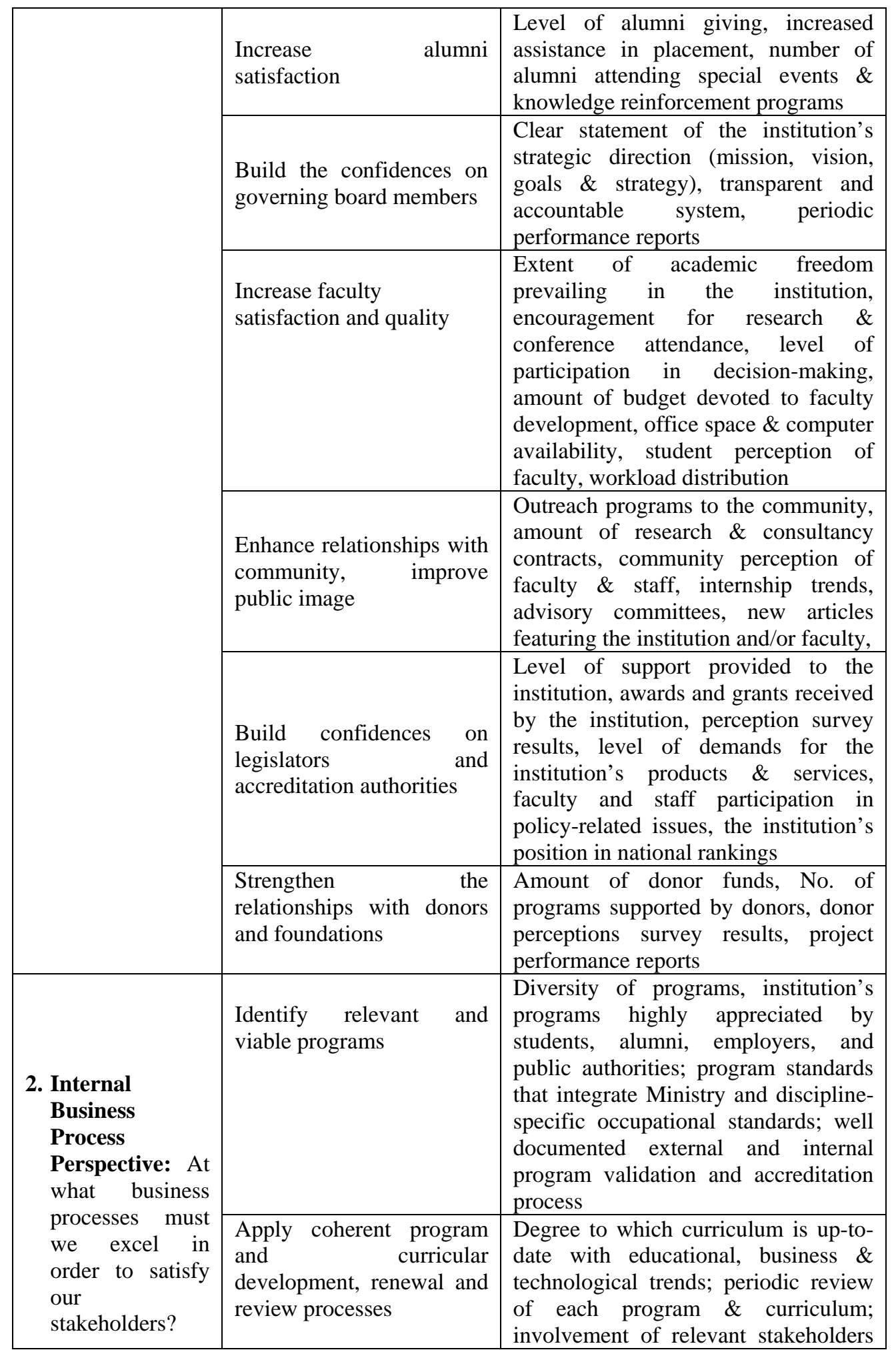




\begin{tabular}{|c|c|c|}
\hline & & $\begin{array}{l}\text { (faculty, students, employers, experts, } \\
\text { legislators) }\end{array}$ \\
\hline & $\begin{array}{l}\text { Enhance teaching and } \\
\text { learning excellence }\end{array}$ & $\begin{array}{l}\text { Evaluation by external reviewers and } \\
\text { employers, peer review, student } \\
\text { satisfaction with teaching quality, } \\
\text { grade point standards, continuous } \\
\text { assessment culture, quality and } \\
\text { technological level of computer labs } \\
\text { and libraries, modern teaching } \\
\text { facilities, presentation capabilities of } \\
\text { faculty }\end{array}$ \\
\hline & $\begin{array}{l}\text { Increase research } \\
\text { productivity }\end{array}$ & $\begin{array}{l}\text { No. of publications and citations, } \\
\text { research grants \& awards, conference } \\
\text { presentations, public lectures \& } \\
\text { colloquiums }\end{array}$ \\
\hline & $\begin{array}{l}\text { Increase knowledge and } \\
\text { technology transfer } \\
\text { activities }\end{array}$ & $\begin{array}{l}\text { No. of licenses, patents, \& invention } \\
\text { disclosures; royalty income }\end{array}$ \\
\hline & $\begin{array}{l}\begin{array}{l}\text { Increase outreach to } \\
\text { community }\end{array} \\
\end{array}$ & $\begin{array}{l}\text { No. of programs and services; no. of } \\
\text { people and organizations served }\end{array}$ \\
\hline & $\begin{array}{l}\text { Integrate the relationship } \\
\text { among teaching, research } \\
\text { \& consultancy }\end{array}$ & $\begin{array}{l}\text { No. of original cases developed for } \\
\text { teaching, projects assigned to students, } \\
\text { models and formulas developed and } \\
\text { applied in classrooms }\end{array}$ \\
\hline & $\begin{array}{l}\text { Enhance efficiency and } \\
\text { effectiveness of services }\end{array}$ & $\begin{array}{l}\text { Prompt catering and admission } \\
\text { services, analysis of use of space, } \\
\text { placement services and opportunities, } \\
\text { guidance and counseling services for } \\
\text { vulnerable (risky) groups, allocation } \\
\text { \& use of equipment \& supplies, cost } \\
\text { effectiveness }\end{array}$ \\
\hline & $\begin{array}{l}\text { Heighten national and } \\
\text { international reputation }\end{array}$ & $\begin{array}{l}\text { No. of programs in the top ranks of } \\
\text { customer demands, no. of quality } \\
\text { research outputs, placement of } \\
\text { graduates, impact assessment reports }\end{array}$ \\
\hline $\begin{array}{l}\text { 3. Learning, } \\
\text { Innovation and } \\
\text { Development } \\
\text { Perspective: } \\
\text { How do you } \\
\text { develop our } \\
\text { capacity and } \\
\text { sustain quality } \\
\text { service? How } \\
\text { well do we } \\
\text { develop and } \\
\text { manage our } \\
\text { human resources? }\end{array}$ & $\begin{array}{l}\text { Enhance teaching and } \\
\text { learning innovation and } \\
\text { faculty development }\end{array}$ & $\begin{array}{l}\text { Qualifications of faculty, quality of } \\
\text { instruction/advising/mentoring, } \\
\text { number and quality of research } \\
\text { outputs \& consultancy service by } \\
\text { faculty, honors and awards received } \\
\text { by the faculty, number of ongoing } \\
\text { instructional development activities, } \\
\text { number of innovations incorporated } \\
\text { into classrooms, seminars presented, } \\
\text { expenditures for teaching } \\
\text { enhancement, frequency of curriculum } \\
\text { changes, number of trainings \& } \\
\text { knowledge upgrading courses } \\
\text { received by faculty \& staff, degree of } \\
\text { favorability of organizational climate, }\end{array}$ \\
\hline
\end{tabular}




\begin{tabular}{|c|c|c|}
\hline & & $\begin{array}{l}\text { amount of performance-based culture } \\
\text { availability, staff satisfaction survey } \\
\text { reports, employee turnover rate }\end{array}$ \\
\hline & $\begin{array}{l}\text { Improve quantity and } \\
\text { quality of facilities } \\
\text { provided to faculty and } \\
\text { staff }\end{array}$ & $\begin{array}{l}\text { Adequacy of classrooms, equipment, } \\
\text { computers \& library; time required to } \\
\text { service, replace \& allocate; \%of } \\
\text { budget for improved facilities }\end{array}$ \\
\hline \multirow{2}{*}{$\begin{array}{l}\text { 4. Financial } \\
\text { Stewardship } \\
\text { Perspective: How } \\
\text { much do we get } \\
\text { and how well do } \\
\text { we utilize financial } \\
\text { resources? }\end{array}$} & $\begin{array}{l}\text { Increase and diversify } \\
\text { revenues }\end{array}$ & $\begin{array}{l}\text { Percentage of revenue by category } \\
\text { over time (government budget, tuition } \\
\text { fee, research \& consultancy contracts, } \\
\text { donors, alumni, catering services, etc.) }\end{array}$ \\
\hline & $\begin{array}{l}\text { Improve budget utilization } \\
\text { and control systems }\end{array}$ & $\begin{array}{l}\text { Efficiency and effectiveness of budget } \\
\text { allocations and spending, } \\
\text { effectiveness of monitoring supplies \& } \\
\text { equipment, transparent accounting } \\
\text { systems, funds totally accountable, } \\
\text { Birr/student ratio, Birr/faculty ratio }\end{array}$ \\
\hline
\end{tabular}

\section{Building balanced scorecard}

The balanced scorecard is not an activity but it is a process which involves some critical steps. Different authorities have different views regarding the number of steps that are required for building organizational scorecard. According to Evans (2002), the overall process of building BSC consists of seven steps, which are broadly categorized under three phases (adopted from the works of Kaplan and Norton).

Phase I: The Strategic Foundation

Step 1: Communicate and align the organization around a clear and concise strategy. This is the fundamental starting point behind everything else. Your strategy is what "feeds" the Balanced Scorecard.

Step 2: Determine the major strategic areas or scope for getting the organization focused on those things the organization can actually do.

Step 3: Build a strategic grid for each major strategic area (step 2) of the business. Out of all the steps in the entire process, this can be the most difficult since we must take our entire strategy (step 1) and transform it into specific terms that everyone can understand. And everything must be linked to form one complete strategic model.

\section{Phase II: Three Critical Components}

Step 4: Establish Measurements: For each strategic objective on each strategic grid, there needs to be at least one measurement. Measurement provides the feedback on whether or not we are meeting our strategic objectives. 
Step 5: Set Targets for each measurement: For each measurement in your scorecard, establish a corresponding target.

Step 6: Launch Programs: Things will not happen unless the organization undertakes formal programs, initiatives or projects. This effectively closes the loop and links us back to where we started-driving the strategy that was formulated in phase I.

Phase III: Deployment

Step 7: Once the Balanced Scorecard has been built, you need to push the entire process into other parts of the organization until you construct a single coherent management system. This pulls everything together, allowing successful execution of your strategy.

In another approach, the Balanced Scorecard Institute has suggested a ninestep approach to build BSC in organizations as demonstrated in their famous circular figure below (see Fig.2).

Figure 2. The Balanced Scorecard Framework

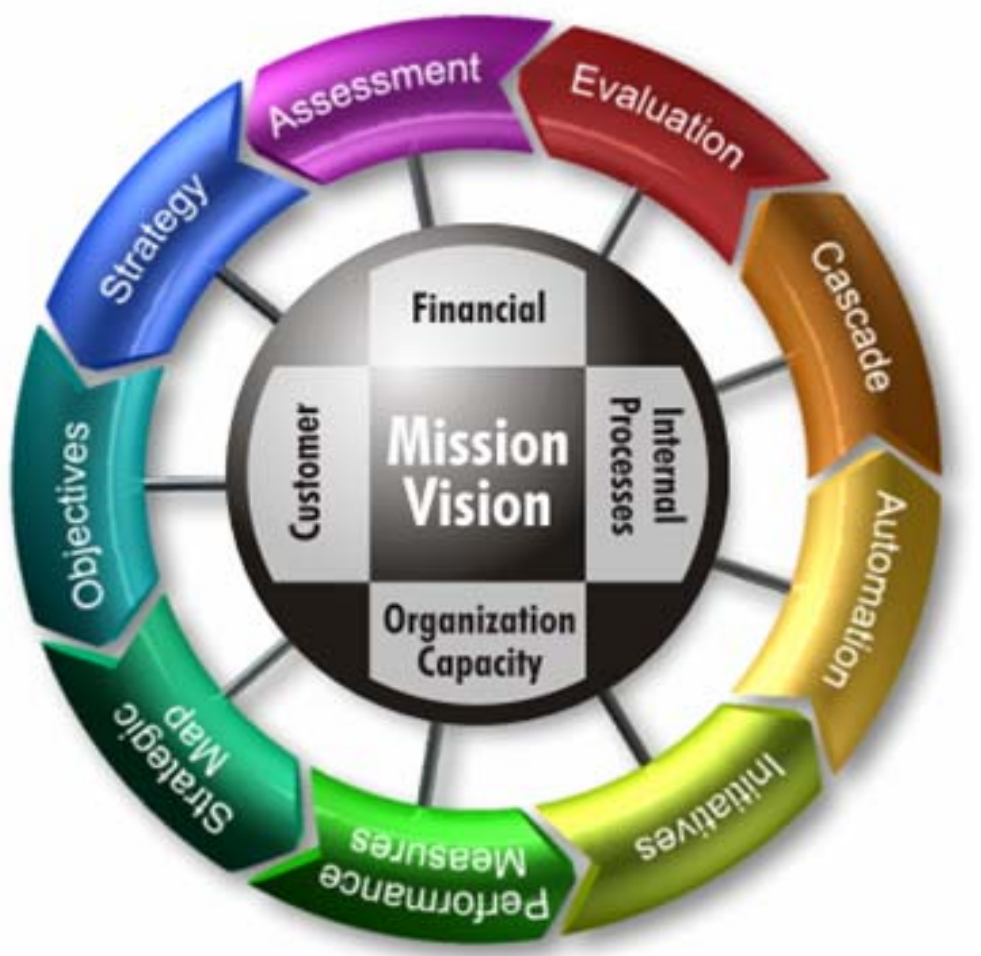

Source: Balanced Scorecard Institute, 1998 
The Institute's award-winning framework, Nine Steps to Success, is a disciplined, practical approach to developing a strategic planning and management system based on the balanced scorecard.

The first step of the scorecard building process starts with an assessment of the organization's Mission and Vision, challenges (pains), enablers, and values. It also includes preparing a change management plan for the organization, and conducting a focused communications workshop to identify key messages, media outlets, timing, and messengers.

The second step is the development of the major elements of the organization's strategy, including strategic results, strategic themes, and perspectives, which are developed through active involvement of workshop participants by focusing their attention on customer needs and the organization's value proposition.

In the third step, the strategic elements developed in steps one and two are decomposed into strategic objectives, which are the basic building blocks of strategy and define the organization's strategic intent. Objectives are first initiated and categorized on the strategic theme level, categorized by perspective, linked in cause-effect linkages (strategy maps) for each strategic theme, and then later merged together to produce one set of strategic objectives for the entire organization

In the fourth step, the cause and effect linkages between the enterprise-wide strategic objectives are formalized in an enterprise-wide strategy map. The previously constructed theme strategy maps are merged into an overall enterprise-wide strategy map that shows how the organization creates value for its customers and stakeholders

In the fifth step, performance measures are developed for each of the enterprise-wide strategic objectives. Leading and lagging measures are identified, expected targets and thresholds are established, and baseline and benchmarking data is developed.

In the sixth step, strategic initiatives are developed that support the strategic objectives. To build accountability throughout the organization, ownership of performance measures and strategic initiatives is assigned to the appropriate staff and documented in data definition tables.

In the seventh step, the implementation process begins by applying performance measurement software to get the right performance information 
to the right people at the right time. Automation adds structure and discipline to implementing the Balanced Scorecard system, helps transform disparate corporate data into information and knowledge, and helps communicate performance information. In short, automation helps people make better decisions because it offers quick access to actual performance data.

In the eight step, the enterprise-level scorecard is 'cascaded' down into business and support unit scorecards, meaning the organizational level scorecard (the first tier) is translated into business unit or support unit scorecards (the second tier) and then later to team and individual scorecards (the third tier). Cascading translates high-level strategy into lower-level objectives, measures, and operational details. Cascading is the key to organization alignment around strategy.

In the ninth step, an Evaluation of the completed scorecard is done. During this evaluation, the organization tries to answer questions such as, "Are our strategies working?', 'Are we measuring the right things?', 'Has our environment changed?' and 'Are we budgeting our money strategically?'

A detail analysis of the two approaches indicates no significant difference exists between them. The nine-steps of BSC reflected on the Balanced Scorecard Institute have been incorporated in the Evan's the seven-step model. However, one of the pluses of the institute's model is that it vividly demonstrates the connections between the various components of strategic planning and management. More specifically, the Institute's BSC model shows a visible connection between the projects and programs that people are working on, the measurements being used to track success, the strategic objectives the organization is trying to accomplish and the mission, vision and strategy of the organization.

\section{Conclusions}

Realizing the drawbacks of being shallowness of traditional business performance measurement tool (which relied on financial considerations only), Kaplan and Norton had introduced the Balanced Scorecard (BSC) in 1992. The BSC is a performance evaluation instrument that forces an organization to identify a number of factors that are crucial to the success of an entity. These "critical success factors" naturally vary from organization to organization. Business houses which adopted BSC had gained unassailable competitive advantages and created the culture of organizational excellence. 
BSC is also gaining acceptance by public as well as the not-for-profit organizations across the globe. However, the adoption and use of BSC in higher education institutions is relatively new with little research carried out in the area. It is due to such theoretical and practical gaps prevalent in Ethiopia that this meta-analytic study was launched by the researcher.

Based on an extensive review of the available literature and exploration of experts' ideas in the field of BSC, the following conclusions are drawn:

1. So far, no HEI in Ethiopia has ever built its scorecard so as to manage its performance based on diverse parameters. Instead, all HEIs rely on traditional measurement tools, which focus on lagging factors of the educational system rather than that of leading factors. Limitations of such measurement approach are widely felt among policy makers and executives of HEIs as they do not provide the complete picture of the current states of the institutions. In particular, the Government of Ethiopia has urged all HEIs to change their management systems to make them quality conscious, dynamic, responsive and accountable to their key stakeholders. Moreover, the fact that Ethiopian HEIs are under reform has necessitated the BSC to be considered as a must apply management tool in those institutions.

2. The framework of HEI's BSC can be built around five major pillars of excellence (strategic thrusts) and four perspectives to be adjusted in a way they are integrated with mission, vision, and strategic objectives of a higher education institution operating in Ethiopia.

a. The strategic thrusts that are closely associated with the mission of a higher learning institution include: academic excellence, size and diversity, outreach and engagement, resource management, and linkages and networks.

b. The proposed four clusters of HEI's performance measurement system include: stakeholder perspective; internal business process perspective; financial stewardship perspective; and learning, innovation and development (LID) perspective.

c. In light of the stipulated pillars of excellence and perspectives, a comprehensive scorecard for HEIs has been crafted constituting about 24 strategic objectives and 100 performance indicators/measurements (see Table 1). 
3. This general framework has been forwarded not as a universal prescription to be followed by all HEIs in Ethiopia but with the condition that it must be adjusted to the vision and strategic direction of a specific institution in a given period of time. To this end, the institutions are advised to adopt a comprehensive and widely recognized model of building a BSC-a Nine Step BSC Building Process as forwarded by the Balanced Scorecard Institute.

\section{Recommendations}

If decision making is to be strategic, the strategy must be directed toward some overarching goals of an institution. Most colleges and universities have mission or vision statements in place that set out in very broad terms the goals of the institutions. It is within the context of these goals that an institution must decide what it will benchmark and what performance it will measure, a process that Kaplan and Norton (1996: 6) describe as "translating the vision". A good translation of the vision occurs when the vision is expressed as an integrated set of objectives and measures that describe the long-term drivers of success. This is possible if the institution has adopted the BSC philosophy and tries its best to build it successfully.

While there is no single formula for building a successful balanced scorecard, there are several necessary steps and precautions for higher education institutions to take in order to build their BSC. In this study, an attempt was made to craft a general framework, which is subject to deliberation and modification by relevant higher education authorities and academia in Ethiopia. Thus, the author forwards the following measures to be taken by the relevant authorities:

1. The adoption and adaptation of the BSC framework begins with clear definition of an institution's mission, vision and strategy. In this regard, management has to play the leading role in defining mission, vision and strategy by involving all key stakeholders. Experience has shown that BSC, when applied properly, establishes focused channels and processes to ensure effective communication throughout the organization. Active communication helps every staff member reach common understanding of the organizational vision, strategies and goals as well as points them to the programmers and desired outcomes. 
2. Intensive capacity building efforts at institutional and unit levels are highly desirable. The necessary infrastructure (e.g. data capturing and storing mechanisms, communication system) has to be put in place.

3. As it has been stated earlier, this is an initial attempt of studying BSC in Ethiopian HEIs, more deliberations have to be made on it at various levels in different forums across the country. To this end, high commitment and involvement by Ministry of Capacity Building, Ministry of Education, Higher Education Institutions' Executives, and academic community are essential leverages. A national framework (roadmap) for HEIs BSC has to be issued through the concerted efforts of relevant authorities, specifically Ministries of Capacity Building and of Education is highly called for.

4. In addition, more research has to be conducted in the area under consideration. 


\section{References}

Baldrige National Quality Program. 2003. Education criteria for performance excellence. Gaithersburg, MD: Author.

Chen Shun-Hsing \& Yang Ching-Cho \& Shiau Juin-Yan. 2006. Scorecard in the performance evaluation of higher education. The TQM Magazine, 18 (2), 190-205.

Chris, P., and Walter, E. 2006. Insights from the Balanced Scorecard: Implementing the Balanced Scorecard at a college of business. Measuring Business Excellence, 10 (3), 15-22.

Gill, A \& Lashine, S. 2003. Business education: A strategic market-oriented focus. International Journal of Educational Management, 17 (5), 188-194.

Kaplan, S.R. 2002. The Balanced Scorecard and nonprofit organizations. Balanced Scorecard Report, November-December, 2002. 1-4.

Kaplan, R. \& Norton, D. 1992. The balanced scorecard: Measures that drive performance. Harvard Business Review: On Measuring Corporate Performance. Boston, MA: Harvard Business School Press, 123-45.

Kaplan, R. \& Norton, D. 1993. Putting the balanced scorecard to work. Harvard Business Review: On Measuring Corporate Performance. Boston, MA: Harvard Business School Press, 147-181.

Kaplan, R. \& Norton, D. 1996. Using the balanced scorecard as a strategic management system. Harvard Business Review: On Measuring Corporate Performance. Boston, MA: Harvard Business School Press, 183-211.

Karathanos, D. \& Karathanos, P. 2005. Applying the balanced scorecard to education. Journal of Education for Business, 80(4), 222-230.

Kettunen, J. 2006. Strategic planning of regional development in higher education. Baltic Journal of Management, 1(3), 259-269.

King, R. 1995. What is higher education for? Strategic dilemmas for the twenty-first century university. Quality Assurance in Education, 3(4), $14-20$. 
Kraus, S., Harms, R., Schwarz, E. J. 2006. Strategic planning in smaller enterprises new empirical findings. Management Research News, 29(6), 334-344.

Kriemadis, A. 1997. Strategic planning in higher education athletic departments. International Journal of Educational Management, 11(6), 238- 247.

Niven, R..P. 2003. Adapting the Balanced Scorecard to fit the public and non-profit sectors. Primerus Consulting, April.

Ruben, B.D. 1999. Toward a balanced scorecard for higher education: Rethinking the college and university excellence indicators framework. Higher Education Forum, 99-02 (http://www.odl.rutgers.edu)

Stewart, A. \& Carpenter-Hubin, J. 2001. The balanced scorecard: Beyond reports and rankings. Planning for Higher Education, Winter 20002001, 37-42.

Tsiakkiros, A., Pashiardis, P. 2002. Strategic planning and education: The case of Cyprus. International Journal of Educational Management, 16(1), 6- 17.

Virtanen, T. 2009. Guidelines for implementing Balanced Scorecard, White paper of QPR (www.qpr.com)

West-Burnham, J., Bush, T., West-Burnham, J.1994. Strategy, policy and planning, The Principles of Educational Management, Longman, Harlow, pp. 77-99.

Yek, M. T. 2007. Quality and performance management of technical education and training in Singapore. Unpublished EdD Portfolio, Edith Cowan University, Perth, Western Australia.

Yek, M.T., Penney, D., \& Seow, A. 2007. Using Balanced Scorecard (BSC) to Improve Quality and Performance of Vocational Education and Training (VET): A Case Study in Singapore. AARE 2007 Conference, November 25 - 29: Fremantle, Australia. 